\title{
Isolasi dan Identifikasi Bakteri Escherichia coli Kontaminan Pada Daging Ayam Broiler Di Rumah Potong Ayam Kabupaten Lamongan
}

\author{
(ISOLATION AND IDENTIFICATION OF Escherichia coli AS BACTERIAL \\ CONTAMINATION IN BROILER CHICKEN MEAT IN POULTRY \\ SLAUGHTERHOUSE LAMONGAN DISTRICT)
}

\author{
Anjani Marisa Kartikasari ${ }^{1 *}$, Iwan Sahrial Hamid ${ }^{2}$, Muhammad Thohawi Elziyad \\ Purnama $^{3}$, Ratna Damayanti ${ }^{2}$, Faisal Fikri' ${ }^{2}$, Ratih Novita Praja ${ }^{4}$ \\ ${ }^{1}$ Mahasiswa Pendidikan Dokter Hewan, ${ }^{2}$ Departemen Ilmu Kedokteran Dasar, ${ }^{3}$ Departemen Anatomi Veteriner, \\ ${ }^{4}$ Departemen Mikrobiologi Veteriner, \\ Fakultas Kedokteran Hewan, Universitas Airlangga, \\ Kampus C Mulyorejo, Surabaya, Jawa Timur, Indonesia, 60115 \\ Telp. (031)5993016, Fax. (031)5993015 \\ *Corresponding author: anjani_marisa@yahoo.com
}

\begin{abstract}
Abstrak
Penelitian ini bertujuan untuk mengisolasi, dan mengidentifikasi bakteri Escherichia coli yang diambil dari daging ayam di Rumah Potong Ayam (RPA) Kabupaten Lamongan. Sampel yang digunakan dalam penelitian ini adalah daging ayam broiler yang di potong pada Rumah Potong Ayam Kabupaten Lamongan pada bulan Juli 2018. Daging ayam yang digunakan sebagai sampel adalah Musculus pectoralis seberat 25 gram. Sampel yang digunakan pada penelitian ini berjumlah 26 sampel daging ayam yang diambil di Rumah Potong Ayam Kabupaten Lamongan. Sampel yang telah diambil dilakukan isolasi secara primer untuk menumbuhkan bakteri pada media Eosin Methylene Blue Agar (EMBA) kemudian dilakukan isolasi sekunder pada media Eosin Methylene Blue Agar (EMBA) yang bertujuan untuk memisahkan bakteri terduga Escherichia coli dengan bakteri Coliform lain. Identifikasi bakteri Escherichia coli menggunakan uji biokimia yaitu Uji IMViC yang berguna untuk mengidentifikasi bakteri Enterobacteriaceae terdiri atas Uji Indol, Uji Methyl Red (MR), Uji Voges Proskauer (VP) dan Uji Sitrat. Hasil penelitian yang dilakukan menunjukkan terdapat 3 sampel positif Escherichia coli dari 26 sampel yang digunakan dalam penelitian ini. Kesimpulan yang didapat dari hasil penelitian adalah sebanyak 3 sampel positif Escherichia coli sedangkan 23 sampel lainnya negatif Escherichia coli dengan persentase sampel positif Escherichia coli adalah 11,5\% sedangkan persentase sampel negatif Escherichia coli adalah 88,5\%.
\end{abstract}

Kata kunci: Escherichia coli, daging ayam, Rumah Potong Ayam, Kabupaten Lamongan

\begin{abstract}
This study aimed to isolate, and identify, Escherichia coli from Poultry Slaughterhouse in Lamongan District. The sample used in this study was broiler chicken meat taken in July 2018 from Poultry Slaughterhouse in Lamongan District. In this study, 25 grams of Musculus pectoralis from chicken meat used as a sample and amount of samples was 26 samples of chicken meat taken from Poultry Slaughterhouse in Lamongan District. The samples were primary isolated to Eosine Methylene Blue Agar (EMBA) as medium to grow bacteria, then secondary isolation was carried out on Eosine Methylene Blue Agar (EMBA) which aims to seperate the Escherichia coli suspected with other Coliform bacteria. Identification of Escherichia coli using biochemical tests, namely IMViC Test which is useful for identifying Enterobacteriaceae bacteria consisting of Indol Test, Methyl Red Test (MR), Voges Proskauer Test (VP) and Citrate Test. The results of the research conducted showed that there were 3 positive samples of Escherichia coli from 26 samples used in this study. The conclusions obtained from the results of the study were, were as many as 3 positive samples of Escherichia coli while the other 23 samples were negative to Escherichia coli with the percentage of positive samples of Escherichia coli was $11.5 \%$ while the percentage of negative samples of Escherichia coli was $88.5 \%$.
\end{abstract}

Key words: Escherichia coli, chicken meat, Poultry Slaughterhouse, Lamongan District 


\section{PENDAHULUAN}

Kebutuhan daging ayam di Indonesia sangat tinggi terutama di Provinsi Jawa Timur. Tahun 2013 hingga 2017 kebutuhan daging ayam di Provinsi Jawa Timur mengalami peningkatan. Data Dinas Peternakan Jawa Timur menunjukkan pada tahun 2013 kebutuhan daging ayam mencapai $162.891 .634 \mathrm{~kg}$, tahun 2014 mencapai $198.016 .292 \mathrm{~kg}$, tahun 2015 mencapai $203.139 .209 \mathrm{~kg}$, tahun 2016 mencapai $219.833 .235 \mathrm{~kg}$ dan $270.881 .906 \mathrm{~kg}$ pada tahun 2017 (Dinas Peternakan Provinsi Jawa Timur, 2018).

Tahun 2016 populasi ayam pedaging di Kabupaten Lamongan mencapai 47.678.903 ekor (Badan Pusat Statistik Kabupaten Lamongan, 2016). Angka produksi daging ayam Kabupaten Lamongan menempati urutan kedua dibawah Kabupaten Tuban dengan produksi 7.530.346 kg pada tahun 2017 sehingga Kabupaten Lamongan menjadi salah satu kabupaten pemasok daging ayam di Jawa Timur bagian Utara (Dinas Peternakan Provinsi Jawa Timur, 2018).

Ayam broiler maupun ayam lokal merupakan sumber daging ayam di Indonesia. Angka permintaan pasar daging ayam yang tinggi berbanding lurus dengan peningkatan produksi daging ayam (Susanto, 2014). Masyarakat cenderung mengkonsumsi daging ayam disebabkan tidak membutuhkan waktu yang panjang dalam pengolahan, harga yang relatif terjangkau dan kandungan lemak yang rendah (Alvarez-Astorga et al, 2002).

Escherichia coli merupakan salah satu bakteri yang sering mencemari daging ayam (Bhunia, 2008). Pada keadaan normal Escherichia coli dapat tumbuh pada saluran pencernaan namun dapat bersifat patogen serta mampu menyerang hewan dan manusia pada keadaan tertentu seperti gangguan di dalam pencernaan serta imunosupresi pada host. Sanitasi yang kurang baik dari manajemen peternakan mengakibatkan cemaran Escherichia coli yang merupakan bakteri environment contaminant yaitu bakteri cemaran lingkungan (Mundi, 2018).
Berdasarkan potensi daging ayam sebagai media yang rentan terkontaminasi bakteri Escherichia coli, maka peneliti ingin mengetahui cemaran Escherichia coli pada daging ayam broiler yang terdapat pada Rumah Potong Ayam (RPA) di Kabupaten Lamongan.

\section{METODE PENELITIAN}

Penelitian ini termasuk penelitian eksploratif laboratorik yaitu penelitian yang bertujuan untuk mengisolasi, dan mengidentifikasi bakteri Escherichia coli yang diisolasi dari daging ayam di Rumah Potong Ayam (RPA) Kabupaten Lamongan.

Sampel yang digunakan dalam penelitian ini adalah daging ayam broiler yang di potong pada Rumah Potong Ayam Kabupaten Lamongan pada bulan Juli 2018. Daging ayam yang digunakan sebagai sampel adalah Musculus pectoralis seberat 25 gram sekurang-kurangnya 26 sampel daging ayam.

Instrumen penelitian yang digunakan adalah sampel atau spesimen daging ayam yang diperoleh dari Rumah Potong Ayam Kabupaten Lamongan kemudian dilakukan isolasi dan identifikasi, dikonfirmasi menggunakan Uji IMViC. Data yang diperoleh dianalisis secara deskriptif. Hasil isolasi dan identifikasi bakteri Escherichia coli yang diisolasi dari daging ayam disajikan dalam bentuk tabel dan gambar.

\section{HASIL DAN PEMBAHASAN}

Penelitian ini menggunakan 26 sampel daging ayam, masing-masing suspensi daging ayam 10\% (25 gram) ditambahkan kedalam Buffered Pepton Water (BPW) dengan perbandingan 1:10. Bakteri ditanam pada media Eosin Methylen Blue Agar (EMBA) sebagai isolasi primer. Koloni khas Escherichia coli yang tumbuh ditanam kembali ke media EMBA lain sebagai isolasi sekunder untuk memisahkan koloni Escherichia coli dengan bakteri Coliform jenis lain pada isolasi primer. Hasil dari isolasi sekunder dari 26 sampel didapatkan 6 sampel yang positif terdapat koloni berwarna hijau metalik seperti yang terlihat pada gambar 1 . 
Tabel 1. Hasil Pengujian Escherichia coli

\begin{tabular}{cccc}
\hline No. & Tempat & $\begin{array}{c}\text { Jumlah Sampel } \\
\text { Positif }\end{array}$ & $\begin{array}{c}\text { Jumlah Sampel } \\
\text { Negatif }\end{array}$ \\
\hline 1 & Rumah Potong Ayam Kabupaten Lamongan & $3(11,5 \%)$ & $23(88,5 \%)$ \\
Total $(\mathrm{n}=26)$ & $11,5 \%$ & $88,5 \%$ \\
\hline
\end{tabular}

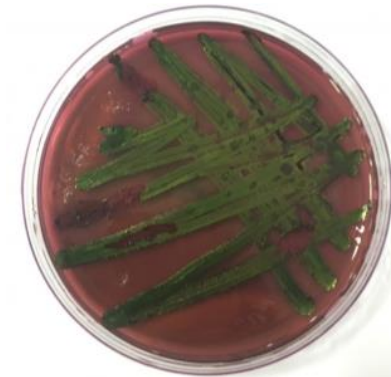

Gambar 1. Media EMBA yang diduga Escherichia coli berwarna hijau metalik
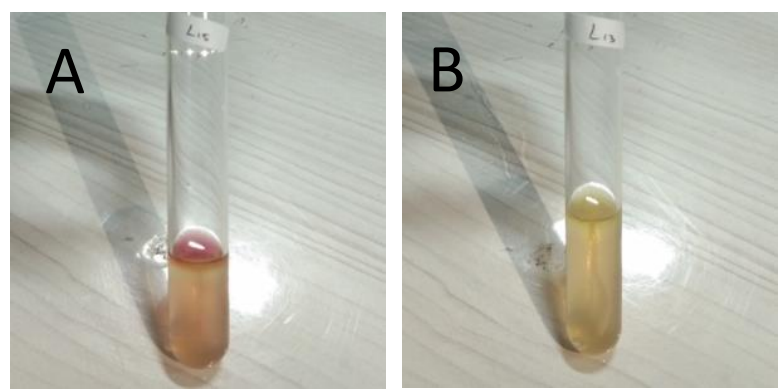

Gambar 2. (A) Hasil uji Indol (+); (B) Hasil uji indol (-)
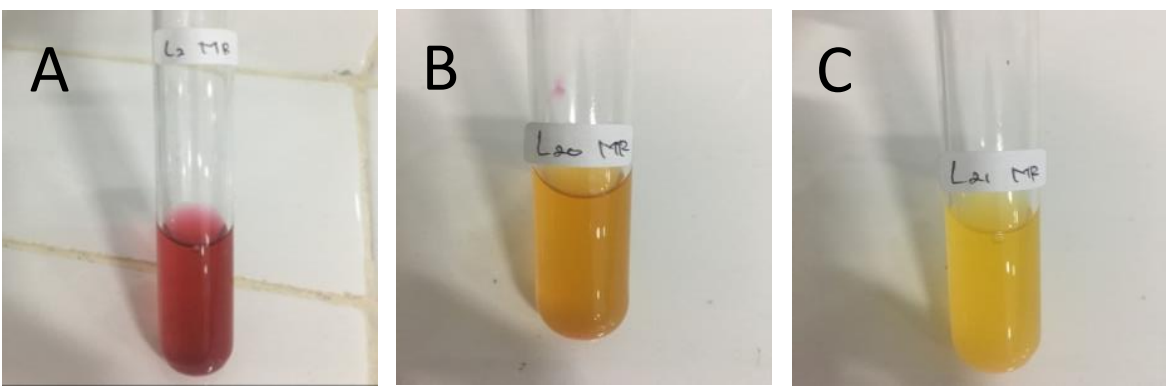

Gambar 3. Hasil (A) uji MR positif kuat; (B) uji MR positif lemah; (C) uji MR negatif

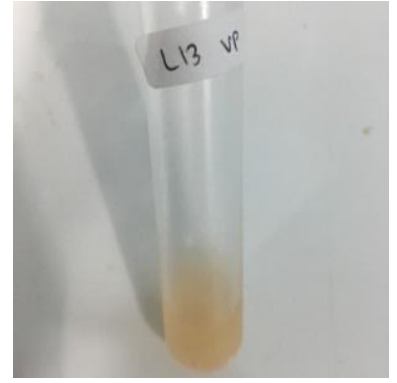

Gambar 4. Uji VP negative
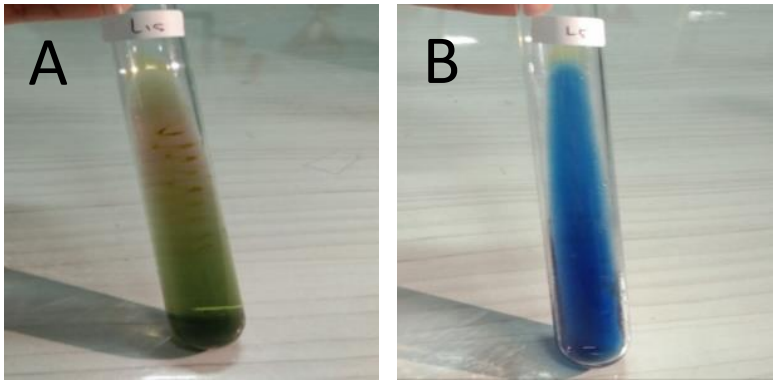

Gambar 5. (A) Uji sitrat negative; (B) uji sitrat positif
Koloni hijau metalik yang tumbuh pada media EMBA dapat diduga koloni tersebut adalah Escherichia coli (Prawesthirini et al, 2009). Bakteri tersebut membentuk koloni metalik dikarenakan adanya reaksi antara bakteri dengan Methylene blue. Koloni yang diduga
Escherichia coli dikonfirmasi menggunakan uji IMViC yang terdiri atas Uji Indol, Uji Methyl Red (MR), Uji Voges Proskauer (VP) dan Uji Sitrat.

Uji Indol yang dilakukan pada media Sulfide Indole Motility (SIM) menggunakan 6 sampel 
terduga Escherichia coli yaitu koloni berwarna hijau metalik atau hitam yang diambil pada media EMBA menunjukkan hasil positif ditandai dengan terbentuknya cincin indol berwarna merah muda setelah ditetesi reagen Kovach pada gambar 2 (Sunarjo, 1994).

Hasil pengamatan untuk uji Methyl Red pada isolat bakteri Escherichia coli adalah positif yang ditunjukkan dengan larutan berwarna merah ataupun orange sedangkan kuning berarti negatif (Rahayu dan Gumilar, 2017). Hasil yang didapatkan dari 6 sampel yang di uji menunjukkan 5 sampel positif, dan 1 sampel negative seperti gambar 3.

Uji Voges Proskauer (VP) negatif untuk Escherichia coli karena Escherichia coli memfermentasikan karbohidrat menjadi produk asam dan tidak menghasilkan produk netral seperti asetonin (Rahayu dan Gumilar, 2017). Pada 6 sampel yang diuji didapatkan hasil negatif dimana tidak ada perubahan warna media dari kuning menjadi pink sampai merah seperti gambar 4.

Hasil pengamatan untuk uji sitrat adalah negatif pada Escherichia coli karena Escherichia coli tidak memanfaatkan sitrat sebagai sumber karbon yang ditunjukan tidak adanya perubahan warna pada media uji sitrat (Rahayu dan Gumilar, 2017). Hasil uji yang dilakukan terhadap 6 sampel didapatkan hasil 3 sampel positif dan 3 sampel negatif kerena adanya perubahan warna pada media seperti gambar 5 .

Hasil uji isolasi dan identifikasi dengan menggunakan uji IMViC yang dilakukan terhadap 26 sampel dari daging ayam yang diperoleh di Rumah Potong Ayam Kabupaten Lamongan menunjukkan terdapat 3 sampel positif Escherichia coli sedangkan 23 sampel lainnya negatif Escherichia coli. Persentase sampel positif Escherichia coli adalah 11,5\% sedangkan persentase sampel negatif Escherichia coli adalah 88,5\% seperti tabel 1.

Angka kontaminasi Escherichia coli pada daging ayam di Rumah Potong Ayam Kabupaten Lamongan tidak terlalu tinggi jika dibandingan dengan penelitian (Sari, 2018) dengan hasil $15,7 \%$ sampel positif menunjukkan adanya kontaminasi Escherichia coli, hal ini bisa dikarenakan Rumah Potong Ayam Kabupaten Lamongan sebagai tempat pengambilan sampel memiliki sanitasi yang lebih baik sehingga angka fecal contaminant yang terjadi tidak terlalu tinggi.

Penelitian (Dewantoro dkk., 2009) menyatakan tingkat prevalensi Escherichia coli pada daging ayam beku di DKI Jakarta sebesar $31,25 \%$, Serang sebesar $27,78 \%$, Bekasi sebesar $27,27 \%$ dan Bogor sebesar 12,50\% sedangkan Setiowati dan Mardiastuti (2009) menyatakan, bahwa sebanyak $28 \%$ sampel daging ayam dari pasar tradisional dan swalayan di DKI Jakarta yang diuji pada tahun 2006 sampai 2009 melebihi BMCM Escherichia coli yang diperbolehkan SNI. DKI Jakarta menunjukkan tingkat prevalensi Escherichia coli yang tinggi akibat higiene yang rendah dan sanitasi yang buruk di tempat pemotongan maupun saat pengolahan atau pengemasan daging ayam di DKI Jakarta.

Kontaminasi Escherichia coli pada daging ayam memiliki beberapa penyebab yaitu, sanitasi yang kurang baik pada kandang, kebersihan yang buruk pada tempat penampungan, dan higienitas peternak yang kurang baik (Rombaut, 2005; Fikri et al., 2017). Sumber cemaran Escherichia coli pada daging ayam selama proses pemotongan yang kontak dengan feses (Bhunia, 2008).

Penyebab kontaminasi Escherichia coli pada daging ayam dapat dikarenakan kondisi kandang pemeliharaan yang kurang baik, tempat pemeliharaan yang jarang dibersihkan dari kotoran ayam dan kondisi kandang yang berdekatan dengan tempat pembuangan kotoran. Management pemeliharaan ayam potong dengan metode diumbar pada kandang yang luas menyebabkan banyak feses yang berceceran serta penggantian alas yang jarang dilakukan menyebabkan bakteri yang terdapat pada feses ayam menempel pada bulu dan kulit ayam, oleh karena itu pergantian alas kandang perlu dilakukan secara rutin dan terjadwal agar lebih bersih dan mengurangi tingkat cemaran bakteri. Kontaminasi yang tinggi dari Escherichia coli pada daging ayam berhubungan erat dengan rendahnya kesadaran akan kebersihan sanitasi 
dan higienis dalam proses penyajian dan penanganan terhadap daging (Suardana dan Swacita, 2009).

Escherichia coli yang mencemari daging ayam umumnya berasal dari ruangan, peralatan, meja pemotongan ayam, serta air yang digunakan selama proses pemotongan hingga pengolahan daging ayam (Fikri et al., 2018). Faktor tersebut dapat mendukung peningkatan jumlah Escherichia coli pada daging ayam. Selain itu, peningkatan jumlah Escherichia coli juga dipengaruhi oleh pengangkutan yang masih sederhana dan kurang higienis, transportasi yang dilakukan secara tidak layak dapat mengakibatkan kontaminasi yang tinggi dari Escherichia coli pada daging ayam (Nugroho, 2005).

Alat pemotong yang kurang bersih dapat menjadi salah satu penyebab kontaminasi Escherichia coli di Rumah Potong Ayam Kabupaten Lamongan. Peralatan yang tidak dibersihkan atau dicuci setiap kali akan digunakan dalam proses pemotongan dapat tercemari oleh bakteri Escherichia coli sehingga pencucian peralatan pemotongan sangat penting sebelum proses pemotongan ayam akan dilakukan (Mundi, 2018).

Cara penyimpanan daging ayam juga menjadi salah satu faktor penting dalam tingkat cemaran bakteri. Tempat penyimpanan daging ayam yang kurang bersih dapat memperbesar resiko terjadinya cemaran. Penyimpanan daging ayam ditempat terbuka disekitar tempat pemotongan yang kurang bersih, serta pegawai Rumah Potong Ayam Kabupaten Lamongan yang menyimpan daging ayam tidak memperhatikan kebersihan tempat penyimpanan menyebabkan peningkatan terjadinya cemaran (Mundi, 2018).

Pertumbuhan mikroba pada produk pangan dapat terjadi karena ketersediaan nutrisi, $\mathrm{pH}$ dan suhu yang sesuai serta kadar air. Oleh karena itu, Escherichia coli dapat tumbuh dengan baik pada daging ayam sesuai dengan kondisi tersebut. Bakteri Escherichia coli dapat tumbuh dengan baik di dalam lemak dan protein yang merupakan sumber nutrisi bagi mikroba. Daging ayam memiliki kandungan lemak dan protein yang tinggi, sehingga daging ayam dapat menjadi media pertumbuhan yang baik untuk Escherichia coli (Rahardjo dan Santoso, 2005).

\section{KESIMPULAN}

Ditemukan sebanyak 3 isolat positif bakteri Escherichia coli dari 26 sampel daging ayam yang diambil di Rumah Potong Ayam Kabupaten Lamongan. Sebanyak 3 sampel positif Escherichia coli sedangkan 23 sampel lainnya negatif Escherichia coli dengan persentase sampel positif Escherichia coli adalah $11,5 \%$ sedangkan persentase sampel negatif Escherichia coli adalah $88,5 \%$.

\section{UCAPAN TERIMA KASIH}

Peneliti mengucapkan terima kasih kepada Dinas Peternakan Kabupaten Lamongan dan Rumah Potong Ayam Kabupaten Lamongan atas izin yang telah diberikan untuk dilakukan penelitian dan para petugas di Rumah Potong Ayam Kabupaten Lamongan.

\section{DAFTAR PUSTAKA}

Álvarez-Astorga, M., Capita, R., Alonso-Calleja, C., Moreno, B., García-Fernández, C. 2002. Microbiological quality of retail chicken byproducts in Spain. Meat Sci., 62(1), 45-50.

Badan Pusat Statistik Kabupaten Lamongan. 2016. Populasi Ternak Unggas Menurut Kecamatan dan Jenis Unggas di Kabupaten Lamongan.

Bhunia, A. 2008. Foodborne microbial pathogens. In Mechanisms and pathogenesis. Springer Science Business Media, New York, NY.

Dewantoro, G. I., Adiningsih, M. W., Purnawarman, T., Sunartatie, T., Afiff, U. 2009. Tingkat prevalensi Escherichia coli dalam daging ayam beku yang dilalulintaskan melalui pelabuhan 
penyeberangan merak. Jurnal Ilmu

Pertanian Indonesia, 14(3), 211-216.

Dinas Peternakan Provinsi Jawa Timur. 2018.

Data Statistik Populasi Ternak Kab/Kota di Jawa Timur.

Dinas Peternakan Provinsi Jawa Timur. 2018. Produksi Daging Ternak Menurut Kabupaten.

Fikri, F., Hamid, I. S., Purnama, M. T. E. 2017. Uji organoleptis, $\mathrm{pH}$, uji eber dan cemaran bakteri pada karkas yang diisolasi dari kios di Banyuwangi. Jurnal Medik Veteriner, 1(1), 23-27.

Fikri, F., Purnama, M. T. E., Saputro, A. L., Hamid, I. S. 2018. Identifikasi Escherichia coli dan Salmonella spp pada Karkas Sapi di Rumah Potong Hewan di Banyuwangi dan Resistensi Terhadap Antibiotika. Jurnal Sain Veteriner, 36(1), 123-128.

Mundi, N. 2018. Karakterisasi Profil Resistensi Antibiotik Pada Escherichia coli yang Diisolasi Dari Daging Ayam yang Dijual di Beberapa Pasar di Surabaya [Thesis]. Fakultas Kedokteran Hewan. Universitas Airlangga.

Nugroho. W.S. 2005. Aspek Kesehatan Masyarakat Veteriner Staphylococcus Bakteri Jahat yang Sering Disepelekan. http//:weesnugroho.staff.ugm.ac.id [03 Januari 2019].

Prawesthirini, S, H. P. Siswanto, A. T. S. Estoepangestie, M. H. Effendi, N. Harijani, G. C. De Vries, Budiarto. dan E. K. Sabdoningrum. 2009. Analisa Kuantitas Susu, Daging dan Telur. Cetakan kelima. Fakultas Kedokteran Hewan Universitas Airlangga.
Rahardjo, A. H. D., dan B. S. Santoso. 2005. Kajian terhadap kualitas karkas broiler yang disimpan pada suhu kamar setelah perlakuan pengukusan. JAP, 7, 1-5.

Rahayu, S. A., dan M. M. H. Gumilar. 2017. Uji Cemaran Air Minum Masyarakat Sekitar Margahayu Raya Bandung Dengan Identifikasi Bakteri Escherichia coli. Indo. J. Pharm. Sci Tech., 4(2), 50-56.

Rombaut, R. 2005. Dairy Microbiology and Starter Cultures. Laboratory of Food Technology and Engineering. Gent University. Belgium.

Sari, R. R. 2018. Daya Hambat Aktinomisetes terhadap Escherichia coli Resisten Antibiotik pada Daging Ayam yang Dilalulintaskan melalui Pelabuhan Tanjung Perak Surabaya [Thesis]. Institut Pertanian Bogor. Bogor.

Setiowati, W. E., dan E. Mardiastuty. 2009. Tinjauan Bahan Pangan Asal Hewan yang ASUH berdasarkan Aspek Mikrobiologi di DKI Jakarta. Prosiding PPI Standardisasi. 111.

Suardana, I. W., dan I. B. N. Swacita. 2009. Higiene Makanan. Kajian Teori Dan Prinsip Dasar. Fakultas Kedokteran Hewan. Universitas Udayana, Denpasar.

Sunarjo. 1994. Penyehatan Air dalam Program Penyediaan dan Pengolahan Air Bersih. Jakarta.

Susanto, E. 2014. Escherichia coli yang Resisten Terhadap Antibiotik yang Diisolasi dari Ayam Broiler dan Ayam Lokal di Kabupaten Bogor [Thesis]. Institut Pertanian Bogor. Bogor. 